\title{
MYD88 Gene Mutation
}

National Cancer Institute

\section{Source}

National Cancer Institute. MYD88 Gene Mutation. NCI Thesaurus. Code C128175.

A change in the nucleotide sequence of the MYD88 gene. 